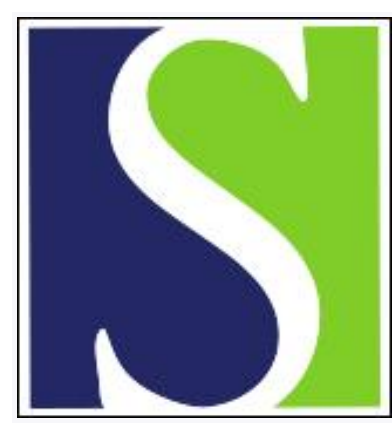

Scand J Work Environ Health 1988;14(3):201-204

https://doi.org/10.5271/sjweh.1940

Issue date: Jun 1988

Levels of dichlorodiphenyltrichloroethane and hexachlorocyclohexane in human adipose tissue of the Indian population.

by Jani JP, Patel JS, Shah MP, Variya MR, Shah YH, Gupta S, Kashyap S

Affiliation: National Institute of Occupational Health, (ICMR), Meghani Nagar, Ahmedabad, India.

This article in PubMed: www.ncbi.nlm.nih.gov/pubmed/2455932 


\section{Levels of dichlorodiphenyltrichloroethane and hexachlorocyclohexane in human adipose tissue of the Indian population}

by Jitesh P Jani, PhD, Jayendra S Patel, MSc, Mahesh P Shah, MSc, Mohmadishak R Variya, BSc, Yogesh H Shah, BSc, Satendrakumar Gupta, PhD, Shrikant Kashyap, MD, PhD ${ }^{1}$

JANI JP, PATEL JS, SHAH MP, VARIYA MR, SHAH YH, GUPTA S, KASHYAP S. Levels of dichlorodiphenyltrichloroethane and hexachlorocyclohexane in human adipose tissue of the Indian population. Scand J Work Environ Health 14 (1988) 201-204. Concentrations of dichlorodiphenyltrichloroethane (DDT) and hexachlorocyclohexane $(\mathrm{HCH})$ were determined in 313 human omental fat samples collected from subjects from all five zones of India during 1977-1980. The median concentration of 2,2-bis(p-chlorophenyl)-1,1-dichloroethylene (p,p'-DDE), total DDT, beta HCH, and total HCH were 3.4, 6.0, 1.3 , and $1.9 \mathrm{mg} / \mathrm{kg}$, respectively. The calculated national mean levels for DDT and HCH were 11.1 and $3.5 \mathrm{mg} / \mathrm{kg}$, respectively. Although the values of DDT and $\mathrm{HCH}$ were not as high as those reported earlier, there is still a need for close monitoring of the bioaccumulation of these chemical residues in the Indian population.

Key terms: human fat, organochlorine compounds, pesticides.

The residues of organochlorine pesticides have received worldwide attention in the last few decades since studies have shown an accumulation of these chemicals in the environment, and in human tissues as well $(9,11,13,27)$. There are numerous reports concerning acute $(12,19,25)$ and chronic $(8,17,30)$ toxic effects of pesticides in man. Higher residues of these chemicals have been reported in patients suffering from diseases such as cirrhosis, atherosclerosis, hypertension, idiopathic amyloidosis, and certain forms of cancer $(6,22,26)$.

The biological monitoring of dichlorodiphenyltrichloroethane (DDT) and hexachlorocyclohexane $(\mathrm{HCH})$ is very important, especially in underdeveloped and developing countries like India, where public health programs are still dependent upon these organochlorine chemicals as pesticides. Earlier reports from India $(2,4,15,23,24)$ have indicated varying levels of DDT and $\mathrm{HCH}$ in human fat samples (table 1). All these reports were confined, however, to the north zone of India.

The present paper reports the results of the first nationwide monitoring program for DDT and $\mathrm{HCH}$ residues in human adipose tissue.

\section{Samples and methods}

The solvents were glass-distilled and free of interfering residues. Organochlorine pesticide standards were obtained from the Environmental Protection Agency, National Institute of Occupational Health, (ICMR),
Meghani Nagar, Ahmedabad-380016, India.

Reprint requests to: Dr JP Jani, National Institute of Occupational Health, Meghani Nagar, Ahmedabad - 380016, India.
Research Triangle Park, North Carolina (USA), with certified purities of $97-100 \%$.

Human omental fat samples $(\mathrm{N}=313)$ were collected during medicolegal autopsies during routine postmortem. The subjects were between the ages of 10 and 60 years (202 men and 111 women) and were without any history of occupational exposure to organochlorine pesticides.

Figure 1 illustrates the sample collection stations of all five zones of India (North, South, East, West, and Central). The samples were freed of nonfatty material and dried with cellulose paper. The insecticides were extracted through the process of weighing a quantity of dried fat in hexane and heating the mixture for $1 \mathrm{~h}$ in a water bath. The undissolved tissue was isolated and extracted in a small portion of fresh hexane. All the hexane extracts were combined and dried for the determination of fat contents. The fat was dissolved in $50 \mathrm{ml}$ of hexane, and $25 \mathrm{ml}$ of the hexane extract was subjected to liquid : liquid extraction (7) with the

Table 1. Mean dichlorodiphenyltrichloroethane (DDT) and hexachlorocyclohexane $(\mathrm{HCH})$ residues in human fat.

\begin{tabular}{|c|c|c|c|}
\hline $\begin{array}{l}\text { Country of } \\
\text { origin }\end{array}$ & $\begin{array}{l}\text { Total } \\
\text { DDT }\end{array}$ & $\begin{array}{l}\text { Total } \\
\mathrm{HCH}\end{array}$ & Reference \\
\hline \multicolumn{4}{|l|}{ India } \\
\hline North zone & 26.0 & . & Dale et al (4) \\
\hline North zone & 21.8 & . & Ramachandran et al (24) \\
\hline North zone & 2.2 & & Bhaskaran et al (2) \\
\hline North zone & 1.8 & 2.3 & Kaphalia \& Seth (15) \\
\hline North zone & 22.3 & 16.9 & Ramachandran et al (23) \\
\hline North zone & 9.1 & 4.3 & Kalra \& Chawla (14) \\
\hline National mean & 11.1 & 3.5 & Present study \\
\hline Turkey & 7.1 & 1.7 & Karakaya \& Ozalp (16) \\
\hline \multirow[t]{2}{*}{ Canada } & 2.6 & 0.07 & Mes et al $(20)$ \\
\hline & 2.1 & 0.16 & Mes et al (21) \\
\hline United Kingdom & 2.5 & 0.29 & Abbott et al (1) \\
\hline South Africa & 6.4 & 6.2 & Wiese (31) \\
\hline Australia & 9.3 & 0.7 & Wassermann et al (28) \\
\hline Japan & 2.47 & 1.54 & Curley et al (3) \\
\hline
\end{tabular}




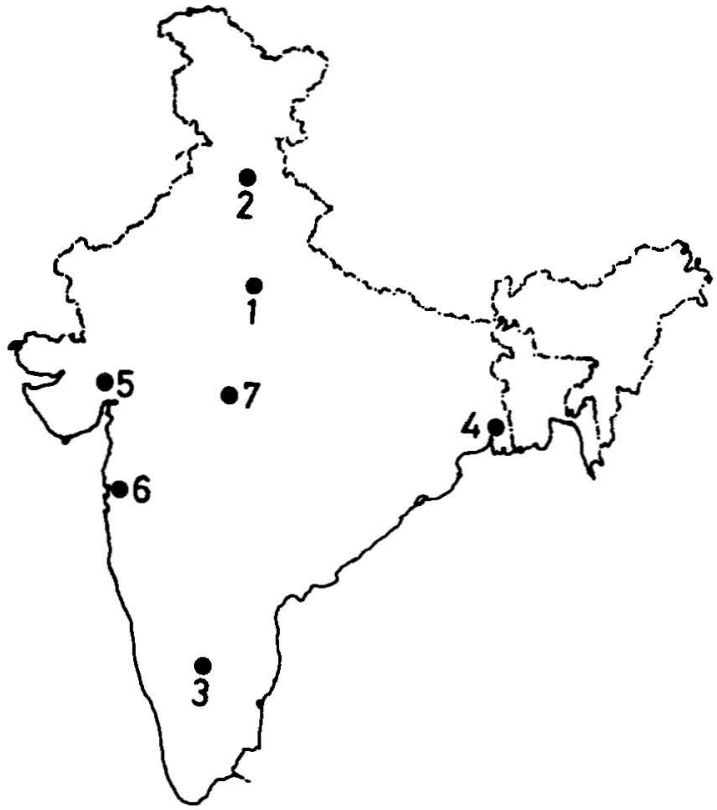

Figure 1. City locations used for sample collections from different zones of India. (North zone: 1 = Agra, 2 = Chandigarh; south zone: 3 = Bangalore; east zone: 4 = Calcutta; west zone: 5 = Ahmedabad, $6=$ Bombay; and central zone: $7=$ Bhopal).

Table 2. Minimum detection limit and percentage recovery of organochlorine pesticides and their metabolites. $(\mathrm{HCH}=$ hexachlorocyclohexane, $p, p^{\prime}-D D E=2,2$-bis-(p-chlorophenyl)1,1-dichloroethylene, DDT $=$ dichlorodiphenyltrichloroethane)

\begin{tabular}{lcc}
\hline Compound & $\begin{array}{c}\text { Minimum } \\
\text { detection limit } \\
(\mu \mathrm{g} / \mathrm{kg})\end{array}$ & $\begin{array}{c}\text { Recovery } \\
(\%)\end{array}$ \\
\hline Alpha HCH & 0.1 & $92-96$ \\
Gamma HCH & 0.04 & $96-101$ \\
Beta HCH & 0.2 & $86-94$ \\
p,p'-DDE & 2.5 & $95-98$ \\
o,p'-DDT & 0.5 & $94-96$ \\
p,p'-DDT & 0.5 & $96-99$ \\
\hline
\end{tabular}

a Five sets.

use of dimethylformamide ( $9: 1$, volume per volume). After partition from dimethylformamide the hexane extract was concentrated to $1 \mathrm{ml}$ for alumina column cleanup. Two grams of $5 \%$ deactivated alumina was wet-packed in a column, and the sample was charged. The column was eluted with $50 \mathrm{ml}$ of hexane, and the eluent was concentrated to $1 \mathrm{ml}$ for analysis by gasliquid chromatography.

Table 2 contains the average recovery and detectability data from the duplicate analysis of two 500 -mg samples of human adipose tissue. In the recovery experiment $0.1 \mathrm{ml}$ of the reference mixture was added to one of the 500-mg human fat samples, and the spiked and unspiked samples were put through the entire procedure. Appropriate corrections were made from the results of the spiked sample analysis, and, depending upon the results of the unspiked sample, the recovery was calculated.

The final analysis was done by gas-liquid chromatography with a nickel-63 $\left(\mathrm{Ni}^{63}\right)$ electron capture detector and a glass column (1.8 $\mathrm{m}$ in length with an outer diameter of $0.6 \mathrm{~cm}$ ) packed with $3 \%$ trifluoropropyl, methyl silicone (DC QF-1) on chromosorb W (80/100). The confirmation of isomers was done on a $5 \%$ OV-17 (50\% phenyl, methyl silicone) column.

The height and area of the unknown concentrations were compared with that of the standards of known concentrations.

\section{Results}

The mean levels of the DDT and HCH isomers in the samples are given in tables 3 and 4, respectively, according to five zones of India. Table 5 presents sumation of the results for all the samples combined. The frequency distribution for the DDT and $\mathrm{HCH}$ residues is shown in figures 2 and 3 , respectively. Figure 4 shows the distribution of the DDT and $\mathrm{HCH}$ residues in the men and women separately and in the different age groups of the subjects from whom the samples were taken.

\section{Discussion}

Table 3 shows that the total DDT was highest (mean $17.2 \mathrm{mg} / \mathrm{kg}$ ) in the samples from the west and lowest $(6.5 \mathrm{mg} / \mathrm{kg})$ in those from the east. For total $\mathrm{HCH}$, shown in table 4 , the maximum $(5.1 \mathrm{mg} / \mathrm{kg})$ and minimum $(1.1 . \mathrm{mg} / \mathrm{kg}$ ) levels were observed in the south and central zones, respectively. Such a wide variation in the bioaccumulation of DDT and $\mathrm{HCH}$ in different zones of India might be due to differences in the intake of these chemicals because of varying residues or due to differences in eating habits or due to a combination of these. Racial and geographic variation in the residues of these chemicals in human body fat have also been reported earlier $(5,18)$.

The calculated national mean levels for DDT, $\mathrm{HCH}$, and their major isomers p,p'-DDE [2,2-bis(p-chlorophenyl)-1,1-dichloroethylene] and beta $\mathrm{HCH}$ were $11.1,3.5,7.4$, and $2.5 \mathrm{mg} / \mathrm{kg}$, respectively. However, the most recurrent values for DDT, $\mathrm{HCH}$, p,p'-DDE, and beta $\mathrm{HCH}$ were only 4.0, 1.1, 2.0, and $0.7 \mathrm{mg} / \mathrm{kg}$, respectively. Furthermore, it was observed that $\mathrm{p}, \mathrm{p}$ '-DDE and beta $\mathrm{HCH}$ contributed about $60-70 \%$ of the total DDT and $\mathrm{HCH}$ in the fat tissues.

The frequency distribution curves for DDT and $\mathrm{HCH}$ residues were found to be highly skewed. Half of the total samples $(50 \%)$ showed DDT residues below the level of $6.0 \mathrm{mg} / \mathrm{kg}$ and $\mathrm{HCH}$ residues below $1.8 \mathrm{mg} / \mathrm{kg}$.

In contradiction to an earlier report (29), no significant correlation was found between the bioaccumulation of DDT or $\mathrm{HCH}$ with age. This finding might be 
Table 3. Mean and range of dichlorodiphenyltrichloroethane (DDT) residues ( $\mathrm{mg} / \mathrm{kg}$ ) in human fat samples from inhabitants of various zones of India.

\begin{tabular}{|c|c|c|c|c|c|c|c|c|c|}
\hline \multirow{2}{*}{ Zone } & \multirow{2}{*}{$\begin{array}{c}\text { Number of } \\
\text { samples }\end{array}$} & \multicolumn{2}{|c|}{$p, p^{\prime}-\mathrm{DDE}$} & \multicolumn{2}{|c|}{$o, p^{\prime}-\mathrm{DDT}$} & \multicolumn{2}{|c|}{$p, p^{\prime}-\mathrm{DDT}$} & \multicolumn{2}{|c|}{ Total DDT } \\
\hline & & Mean & Range & Mean & Range & Mean & Range & Mean & Range \\
\hline East & 45 & 4.2 & $0.3-16.4$ & 0.01 & $0.2-2.4$ & 1.9 & $0.4-11.8$ & 6.5 & $1.4-37.1$ \\
\hline West & 114 & 12.0 & $0.2-128.1$ & 0.7 & $0.4-23.0$ & 3.2 & $0.1-25.0$ & 17.2 & $1.3-176.1$ \\
\hline North & 24 & 5.9 & $0.4-51.3$ & 0.3 & $0.3-5.0$ & 8.5 & $0.9-70.6$ & 15.4 & $1.9-131.6$ \\
\hline South & 116 & 4.3 & $0.2-64.4$ & 0.9 & $0.4-20.7$ & 2.2 & $0.03-12.9$ & 7.8 & $0.2-80.7$ \\
\hline Central & 14 & 6.4 & $0.3-29.9$ & 0.2 & $0.9-12.8$ & 1.9 & $0.1-24.1$ & 9.2 & $1.0-37.1$ \\
\hline
\end{tabular}

Table 4. Mean and range of hexachlorocyclohexane $(\mathrm{HCH})$ residues $(\mathrm{mg} / \mathrm{kg})$ in human fat samples from inhabitants of various zones of India.

\begin{tabular}{|c|c|c|c|c|c|c|c|c|c|}
\hline \multirow{2}{*}{ Zone } & \multirow{2}{*}{$\begin{array}{l}\text { Number of } \\
\text { samples }\end{array}$} & \multicolumn{2}{|c|}{ Alpha $\mathrm{HCH}$} & \multicolumn{2}{|c|}{ Gamma $\mathrm{HCH}$} & \multicolumn{2}{|c|}{ Beta $\mathrm{HCH}$} & \multicolumn{2}{|c|}{ Total $\mathrm{HCH}$} \\
\hline & & Mean & Range & Mean & Range & Mean & Range & Mean & Range \\
\hline East & 45 & 0.3 & $0.06-0.6$ & 0.3 & $0.01-0.8$ & 1.05 & $0.06-3.9$ & 1.6 & $0.1-4.84$ \\
\hline West & 114 & 0.4 & $0.01-4.6$ & 0.2 & $0.02-1.7$ & 2.6 & $0.10-17.5$ & 3.2 & $0.2-20.6$ \\
\hline North & 24 & 0.5 & $0.01-5.5$ & 0.2 & $0.02-1.3$ & 1.5 & $0.07-9.0$ & 2.2 & $0.2-11.0$ \\
\hline South & 116 & 1.0 & $0.01-21.0$ & 1.2 & $0.01-28.0$ & 2.9 & $0.01-15.7$ & 5.1 & $0.02-94.5$ \\
\hline Central & 14 & 0.2 & $0.05-0.5$ & 0.04 & $0.01-0.08$ & 0.8 & $0.3-1.5$ & 1.1 & $0.25-1.9$ \\
\hline
\end{tabular}

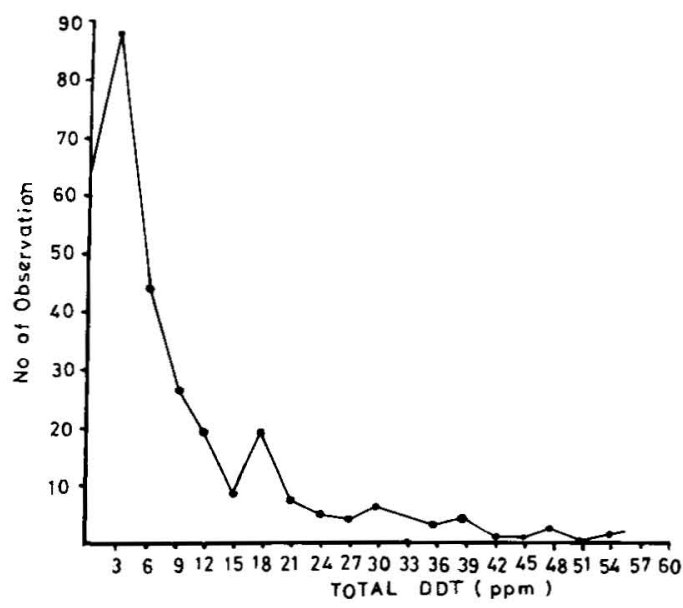

Figure 2. Frequency distribution curve of dichlorodiphenyltrichloroethane (DDT) residues in human fat samples. (No = number)

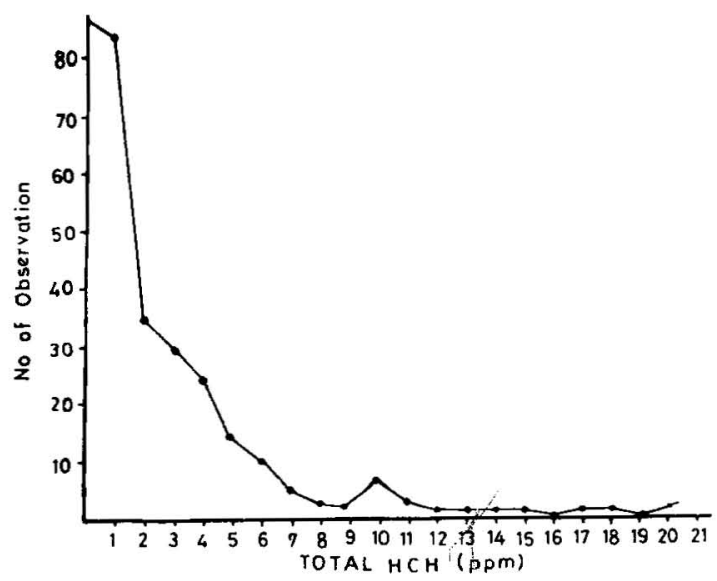

Figure 3. Frequency distribution curve of hexachlorocyclohexane $(\mathrm{HCH})$ residues in human fat samples. (No = number)
Table 5. Average dichlorodiphenyltrichloroethane (DDT), hexachlorocyclohexane $(\mathrm{HCH})$, and their isomer residue levels in human fat samples $(\mathrm{N}=313)$. ( $\left(\mathrm{p}, \mathrm{p}^{\prime}\right.$-DDE $=2$ '2-bis-(p-chlorophenyl)-1,1-dichloroethylene)

\begin{tabular}{lrcccc}
\hline Compound & $\begin{array}{c}\text { Mean } \\
(\mathrm{mg} / \mathrm{kg})\end{array}$ & $\begin{array}{c}\text { Median } \\
(\mathrm{mg} / \mathrm{kg})\end{array}$ & $\begin{array}{c}\text { Mode } \\
(\mathrm{mg} / \mathrm{kg})\end{array}$ & $\begin{array}{c}\text { Range } \\
(\mathrm{mg} / \mathrm{kg})\end{array}$ & $\begin{array}{c}\text { Range covering } \\
\text { central 90\% } \\
\text { observations } \\
(\mathrm{mg} / \mathrm{kg})\end{array}$ \\
\hline Total DDT & 11.1 & 6.0 & 4.0 & $0.2-176.1$ & $0.7-32.7$ \\
p,p'-DDE & 7.4 & 3.4 & 2.0 & $0.2-128.1$ & $0.3-27.3$ \\
Total HCH & 3.5 & 1.9 & 1.1 & $0.03-94.6$ & $0.2-10.5$ \\
Beta HCH & 2.5 & 1.3 & 0.7 & $0.01-45.7$ & $0.12-7.9$ \\
\hline
\end{tabular}

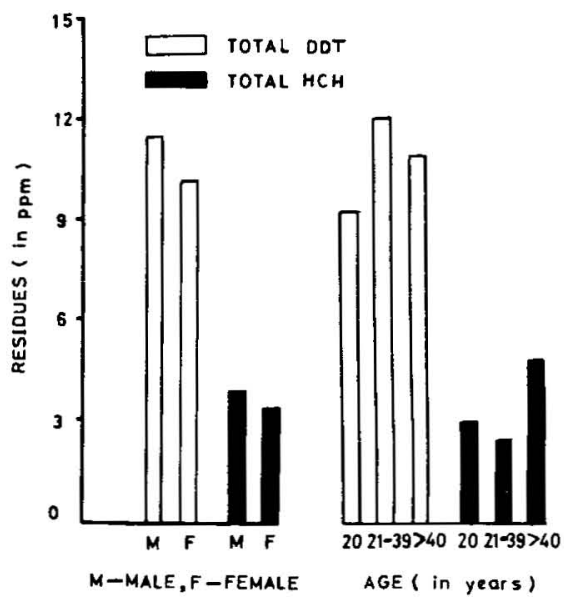

Figure 4. Distribution of dichlorodiphenyltrichloroethane (DDT) and hexachlorocyclohexane $(\mathrm{HCH})$ residues according to the age and sex of the person from which the samples were taken. 
due to a relatively high daily dietary intake of these chemicals as residues in food materials from infancy $(10,13,24)$. Furthermore, the residues show somewhat higher levels for men than for women (figure 4).

Although the residue buildup of DDT and $\mathrm{HCH}$ in the general population of India was not found to be as high as reported earlier $(4,23,24)$, there is still need for close monitoring of the bioaccumulation of these chemical residues in Indians.

\section{Acknowledgments}

We gratefully acknowledge Drs BB Chatterjee, BN Datta, B Lahiri, SR Kamath, AP Desai, HH Shah, and CR Ramachandran for their help with the sample collection. We are thankful to Mr PM Chacko for his secretarial assistance.

\section{References}

1. Abbott DC, Collins GB, Goulding R. Organochlorine pesticide residues in human fat in the United Kingdom 1969-71. Br Med J 3 (1972) 553-556.

2. Bhaskaran M, Sharma RC, Bhide NK. DDT levels in human fat samples in Delhi area. Indian J Exp Biol 17 (1979) 1390-1392.

3. Curley A, Burse WW, Jennings RW, Villanueva EC. Chlorinated hydrocarbon pesticides and related compounds in adipose tissue from people of Japan. Nature (London) 242 (1973) 338-340.

4. Dale WE, Copeland MF, Hayes WJ Jr. Chlorinated insecticides in the body fat of people in India. Bull WHO 33 (1965) 471-477.

5. Davies JE, Edmundson WF, Schneider NJ, Cassady JC. Problems of prevalence of pesticide residues in humans. Pestic Monit J 2 (1968) 80-85.

6. Diechmann WB, Radomski JL. Retention of pesticides in human adipose tissue-preliminary report. Ind Med Surg 37 (1968) 218-219.

7. Faubert Maunder MJ, Egan H, Godly EW, Hammond EW, Roburn J, Thompson J. Clean up of animal fats and dairy products for the analysis of chlorinated pesticide residues. Analyst (London) 89 (1964) 168-172.

8. Gupta SK, Jani JP, Saiyed HN, Kashyap SK. Health hazards in pesticide formulators exposed to a combination of pesticides. Indian J Med Res 79 (1984) 666-672.

9. Gupta SK, Neena Srivastava, Patel JS, Shah MP, Jani JP, Chatterjee SK, Kashyap SK. Organochlorine insecticide residues in fat of people from urban centres in India-II. Pesticides 16 (1982) 11-13.

10. Gupta SK, Saramma Verghese, Chatterjee SK, Kashyap SK. Organochlorine insecticide residues in cooked meal samples in India. Pesticides 16 (1982) 8-9.

11. Gupta SK, Saramma Verghese, Shah MP, Jani JP, Chatterjee SK, Kashyap SK. Organochlorine insecticide residues in human fat from urban centres of IndiaIII. Pesticides 17 (1984) 14-16.

12. Herbst $\mathbf{M}$, Bodenstein $\mathrm{G}$. Toxicologie des lindan. In: Ulmann E (Hrsg). Lindan. Schillinger, Freiburg S, pp 23-82. (Monographie eines insektiziden Wirkstoffs).

13. Jensen S, Johnels AG, Olsson M, Otterlind G. DDT and $\mathrm{PCB}$ in marine animals from Swedish water. Nature
(London) 224 (1969) 247-250.

14. Kalra RL, Chawla RP. Studies on pesticide residues and monitoring of pesticide pollution. Punjab Agricultural University, Ludhiana (India) 1983. (PL-480 project report).

15. Kaphalia BS, Seth TD. Chlorinated pesticide residues in blood plasma and adipose tissue of normal and exposed human population. Indian J Med Res 77 (1983) $245-247$.

16. Karakaya AE, Ozalp S. Organochlorine pesticides in human adipose tissue collected in Ankara (Turkey) 1984-1985. Bull Environ Contam Toxicol 38 (1987) $941-945$.

17. Kashyap SK. Health surveillance and biological monitoring of pesticide formulators in India. Toxicol Lett 33 (1986) 107-114.

18. Kutz FW, Yobs AR, Strassman SC. Racial statification of organochlorine insecticide residues in human adipose tissue. J Occup Med 19 (1977) 619-622.

19. Mayersdorf A, Israeli R. Toxic effects of chlorinated hydrocarbon insecticides. Arch Environ Health 28 (1974) 159-163.

20. Mes J, Campbell DS, Robinson RN, Davies DJ. Polychlorinated biphenyl and organochlorine pesticide residues in adipose tissue of Canadians. Bull Environ Contam Toxicol 17 (1977) 196-203.

21. Mes J, Davies DJ, Turton D. Polychlorinated biphenyl and other chlorinated hydrocarbon residues in adipose tissue of Canadians. Bull Environ Contam Toxicol 28 (1982) 97-104.

22. Radomski JL, Deichmann WB, Clizer EE. Pesticide concentrations in the liver, brain and adipose tissue of terminal hospital patients. Food Cosmet Toxicol 6 (1968) 209-220.

23. Ramachandran M, Banerjee BD, Gulati M, Anjana Grover, Zaidi SSA, Hussain QZ. DDT and BHC residues in the body fat and blood samples from some Delhi hospitals. Indian J Med Res 80 (1984) 590-593.

24. Ramachandran M, Sharma MID, Sharma SC, Mathur PS, Arvindrakshan AG, Edward GC. DDT and its metabolites in the body fat of Indians. J Commun Disord 6 (1974) 256-259.

25. Solomon LM, Fahrner L, West DP. Gamma benzene hexachloride toxicity: A review. Arch Dermatol 113 (1977) 353-357.

26. Unger M, Olsen J. Organochlorine compounds in the adipose tissue of diseased people with and without cancer. Environ Res 23 (1980) 257-263.

27. Slorach SA, Vaz R. Assessment of human exposure to selected organochlorine compounds through biological monitoring. United Nations Environment Programme/ World Health Organization (UNEP/WHO), Uppsala (Sweden) 1983

28. Wassermann M, Curnow DH, Forte PN, Groner Y. Storage of organochlorine pesticide in the body of people in Western Australia. Ind Med Surg 37 (1968) 295-300.

29. Wassermann M, Tomatis L, Wassermann D. Epidemiology of organochlorine insecticides in the adipose tissue of Israelis. Pestic Monit J 8 (1974) 1-7.

30. West 1. Lindane and hematologic reactions. Arch Environ Health 15 (1967) 97-101.

31. Wiese JH. Pesticides and South African population. S Afr Med J 50 (1976) 1801-1805.

Received for publication: 5 June 1987 
Inhaled dust and disease. By Paul F Holt. John Wiley \& Sons, Chichester-New York-Brisbane-Toronto-Singapore 1987. 325 p. ISBN 0-471-91665-2. (Price: GBP 35.50)

Professor PF Holt is excellently qualified to write an overview on inhaled dusts and their related diseases. $\mathrm{He}$ started to research industrial lung diseases 50 years ago and since 1975 has been Professor Emeritus at the Reading University in the United Kingdom.

The causal relationship between the regular inhalation of various kinds of dust and disease is well known. The dusts discussed in this book cover a wide range of inorganic and organic types, eg, asbestos, coal, quartz, china clay, talc, cotton, etc. The primary emphasis is placed, however, on fibrous silicates and, especially, asbestos. Asbestos-related questions are discussed in 10 of the 22 chapters of the book.

The fact that mesothelioma has been discussed in detail is not surprising in light of the author's report of a doubling in incidence in Great Britain in 1967-1976 and again in 1976-1984. Mesothelioma is considered a malignant tumor. Benign types are not treated. Mesothelioma is nowadays regarded as a disease that is nearly always caused by asbestos exposure. Children are at a greater risk than adults to incur mesothelioma if exposed to asbestos dust. Sometimes an environmental exposure to asbestos in childhood has resulted in death from mesothelioma many years later. In a few young children however the occurrence of mesothelioma is probably not related to exposure to asbestos. The most disconcerting aspect of the relationship between malignant mesothelioma and asbestos is the documented association of mesothelioma with apparently low levels of exposure for relatively brief periods in the past. This phenomenon implies a lack of a dose-response relationship.

The association between lung cancer and asbestos exposure is also discussed in the book. Professor Holt states that the risk of developing bronchial carcinoma appears to be directly related to the intensity of exposure to asbestos. A linear relationship between accumulated asbestos exposure and lung cancer has been widely accepted on the basis of the results of studies on asbestos textile and factory workers and laggers. Other types of dose-response relationships are also discussed, as are also the major findings of experimental research.

The health hazards of man-made mineral fibers are not so clear. Large epidemiologic studies of populations exposed to these fibers have shown no excess occurrence of mesotheliomas, whereas an excess of lung cancer has been reported for workers with 30 years or more since their first exposure. The early environmental conditions of rock-wool and slag-wool production might have helped to increase the incidence of lung cancer in this group of workers.

On the whole the book is very well written and easy to read. It covers the main epidemiologic evidence of the various exposures and diseases, and it illustrates the size of the problem. This book is valuable for occupational health and safety experts who are interested in various exposures which may cause occupational lung diseases. The diseases themselves have not been described in detail however.

Matti S Huuskonen, MD, MSc

Uusimaa Regional Institute of Occupational Health

Arinatie $3 \mathrm{~A}$

SF-00370 Helsinki Finland 